\title{
Geographers and the Reconstruction of Europe.*
}

\section{By John McFarlane, M.A.}

I $N$ the rearrangement of European States which has taken place geographical conditions have, perhaps, not always had the consideration which they deserve, but in an inquiry such as that upon which we are engaged they naturally occupy the first place. It is to the land within the frontier, and not to the frontier itself, that our main consideration should be given. The factors which we have to take into account are those which enable a people to lead a common national life, to develop the economic resources of the region within which they dwell, to communicate freely with other peoples, and to provide not only for the needs of the moment, but so far as possible for those arising out of the natural increase of the population. The principle of self-determination has likewise played an important, if not always a welldefined, part in the rearrangement of Europe. The basis upon which the new nationalities have been constituted is, on the whole, ethnical, though it is true that within the main ethnical divisions advantage has been taken of the further differentiation in racial characteristics arising out of differences in geographical environment, history, language, and religion. But no more striking illustration could be adduced of the strength of ethnic relationships at the present time than the union of the Czechs with the Slovaks, or of the Serbs with the Croats and the Slovenes. Economic considerations, of course, played a great part in the settlement arrived at with Germany, but, on the whole, less weight has been attached to them than to ethnic conditions.

When we come to examine the application of the principles which I have indicated to the settlement of Europe we shall, I think, find that the promise of stability is greatest in those cases where geographical and ethnical conditions are most in harmony, and least where undue weight has been given to conditions which are neither geographical nor ethnical.

The restoration of Alsace-Lorraine to France had always been treated as a foregone conclusion in the event of a successful termination of the war against Germany. From the geographical point of view, however, there are certainly objections to the inclusion of Alsace within French territory. From the economic point of view, however, the great deposits of iron ore in Lorraine constitute its chief attraction for France to-day, just as they appear to have constituted its chief attraction for Germany half a century ago. But the transfer of the province from Germany, which has built up a great industry on the exploitation of its mines, to France, which does not possess in sufficient abundance coal for smelting purposes, together with other arrangements of a territorial or quasi-territorial nature made partly at least in consequence of this transfer, at once raises questions as to the extent to which the economic stability of Germany is threatened. In regard to coal the position is serious. We need not, perhaps, be unduly impressed by the somewhat alarmist attitude of $\mathrm{Mr}$. Keynes, who estimates that on the basis of the I9I3 figures Germany, as she is now constituted, will require for the pre-war efficiency of her railways and industries an annual output of I $10,000,000$ tons, and that instead she will have in future only $100,000,000$ tons, of which $40,000,000$ tons will be mortgaged to the Allies. In arriving at these figures $\mathrm{Mr}$. Keynes

- From the opening address of the President of Section E (Geography) delivered at the Cardiff meeting of the British Association on August 24. No. 2655 , VOL. IO6] has made an allowance of $18,000,000$ tons for decreased production, one-half of which is caused by the German miner having shortened his shift from eight and a half to seven hours per day. This is certainly a deduction which we need not take into account. Mr. Keynes also leaves out of his calculation the fact that previous to the war about I0,000,000 tons per year were sent from Upper Silesia to other parts of Germany, and there is no reason to suppose that this amount need be greatly reduced, especially in view of article 90 of the Treaty of Versailles, which provides that "for a period of fifteen years Poland will permit the produce of the mines of Upper Silesia to be available for sale to purchasers in Germany on terms as favourable as are applicable to like products sold under similar conditions in Poland or in any other country." We have further to take into account the opportunities for economy in the use of coal, the reduction in the amount which will be required for bunkers, the possibility of renewing imports from abroad-to a very limited extent indeed, but still to some extent-and the fact that the French mines are being restored more rapidly than at one time appeared possible. (On the basis of the production of the first four months of I920 Germany could already reduce her treaty obligations to France by $\mathrm{I}, 000,000$ tons per year.) Taking all these facts into account, it is probably correct to say that when Germany can restore the output of the mines left to her to the I9I3 figure, she will, as regards her coal supply for industrial purposes, be in a position not very far removed from that in which she was in IgIo, when her total consumption, apart from that at the mines, was about $100,000,000$ tons. Our general conclusion, then, is that the territorial arrangements which have been made do not necessarily imperil the economic stability of Germany. The economic consequences of the war are really much more serious than the economic consequences of the peace. Germany has for ten vears to make good the difference between the actual and the prewar production of the French mines which she destroyed. Her own miners are working shorter hours, and as a result her own production is reduced, and as British miners are doing the same she is unable to import from this country. For some years these deductions will represent a loss to her of about $40,000,000$ tons per annum, and will undoubtedly make her position a serious one. But to give her either the Saar or the Upper Silesian coalfields would be to enable her to pass on to others the debt which she herself has incurred. The reduction of her annual deliveries of coal to France, Belgium, and Italy was, indeed, the best way in which to show mercy to her.

The position of Poland is geographically weak, partly because its surface features are such that the land has no well-marked individuality, and partly because there are on the east and west no natural boundaries to prevent invasion or to restrain the Poles from wandering far beyond the extreme limits of their State. Polish geographers themselves appear to be conscious of this geographical infirmity. It is, then, to racial feeling rather than to geographical environment that we must look for the basis of the new Polish State, but the intensity with which this feeling is likely to operate varies considerably in different parts of the region which it is proposed to include. The population is sufficiently large and the 
Polish element within it sufficiently strong to justify its independence on ethnical grounds. Moreover, the alien elements which it contains are united neither by racial ties nor by contiguity of settlement. Considered as a whole, Poland is at least as pure racially as the United States. When we consider the economic resources of Poland we see that they also make for a strong and united State. It is true that in the past the country has failed to develop as an economic unit, but this is a natural result of the partitions and of the different economic systems which have prevailed in different regions. Even now, however, we can trace the growth of two belts of industrial activity which will eventually unite these different regions. One is situated on the coalfield running from Oppeln in Silesia by Cracow and Lemberg, and is engaged in mining, agriculture, and forestry; while the other extends from Posen by Lodz to Warsaw, and has much agricultural wealth and an important textile industry. Moreover, the conditions, geographical and economic, are favourable to the growth of international trade. If Poland obtains Upper Silesia she will have more coal than she requires, and the Upper Silesian fields will, as in the past, export their surplus produce to the surrounding countries, while the manufacturing districts will continue to find their best markets in the Russian area to the east. The outlets of the State are good, for not only has it for all practical purposes control of the port of Danzig, but it is able to share in the navigation of the Oder and it has easy access to the south by way of the Moravian Gap. It seems obvious, therefore, that Poland can best seek compensation for the weakness of her geographical position by developing the natural resources which lie within her ethnic frontiers. By such a policy the different parts of the country will be more closely bound to one another than it is possible to bind them on a basis of racial affinity and national sentiment alone. Moreover, Poland is essentially the land of the Vistula, and whatever is done to improve navigation on that river will similarly terd to have a unifying effect upon the country as a whole. The mention of the Vistula, however, raises one point where geographical and ethnical conditions stand in marked antagonism to one another. The Poles have naturally tried to move down-stream to the mouth of the river which gives their country what little geographical individuality it possesses, and the Polish corridor is the expression of that movement. On the other hand, the peoples of East and West Prussia are one and the same. The geographical reasons for giving Poland access to the sea are no doubt stronger than the historical reasons for leaving East Prussia united to the remainder of Germany, but strategically the position of the corridor is as bad as it can be, and the solution arrived at may not be accepted as final. Lastly, we may consider the case of East Galicia, which the Poles claim not on geographical grounds, because it is in reality part of the Ukraine, and not on ethnical grounds, because the great majority of the inhabitants are Little Russians, but on the ground that they are, and have for long been, the ruling race in the land. It may also be that they are not uninfluenced by the fact that the region contains considerable stores of mineral oil.

Czecho-Slovakia is in various ways the most interesting country in the reconstructed Europe. Both geographically and ethnically it is marked by some features of great strength, and by others which are a source of considerable weakness to it. Bohemia by its physical structure and its strategic position seems designed by Nature to be the home of a strong and homogeneous people. Moravia attaches itself No. 2655 , VOL. IO6] more or less naturally to it, since it belongs in part to the Bohemian massif, and is in part a dependency of that massif. Slovakia is Carpathian country, with a strip of the Hungarian plain. Thus, while Bohemia possesses great geographical individuality, and Slovakia is at least strategically strong, Czecho-Slovakia as a whole does not possess geographical unity, and is in a sense strategically weak, since Moravia, which unites the two upland wings of the State, lies across the great route which leads from the Adriatic to the plains of Northern Europe. The country might easily, therefore, be cut in two as the result of a successful attack, either from the north or from the south. Later I shall endeavour to indicate certain compensations arising out of this diversity of geographical features, but, for the moment at least, they do not affect our argument. We have, further, to note that the geographical and ethnical conditions are not altogether concordant. In Bohemia we feel justified in arguing that here at least the governing factors are and must be geographical. To partition a country which seems predestined by its geographical features to be united and independent would give rise to an intolerable sense of injustice. In Slovakia also there are racial differences. Within the mountain area the Slovaks form the great majority of the population, but in the valleys and on the plains of the Danube, to which the valleys open out, the Magyar element predominates. Moreover, it is the Magyar element which is racially the stronger, and before which the Slovaks are gradually retiring. Geographical and ethnical conditions, therefore, unite in fixing the political frontier between Magyar and Slovak at the meeting place of hill and plain. But on the west such a frontier would have been politically inexpedient because of its length and irregularity, and economically disadvantageous because the river valleys, of which there are about a dozen, would have had no easy means of communication with one another or with the outside world. Hence the frontier was carried south to the Danube, and about $1,000,000$ Magyars were included in the total population of $3,500,000$. The danger of transferring territory not on geographical or ethnical, but on economic, grounds could not be more strikingly illustrated. With regard to economic development, the future of the new State would appear to be well assured. Bohemia and Moravia were the most important industrial areas in the old Austrian Empire, and Slovakia, in addition to much good agricultural land, contains considerable stores of coal and iron. But if Czecho-Slovalia is to be knit together into a political and economic unit, its communications will have to be developed. We have already suggested that the geographical diversity of the country offers certain compensations for its lack of unity, but these cannot be taken advantage of until its different regions are more closely knit together than they are at present. The north of Bohemia finds its natural outlet both by rail and water through German ports. The south-east of Bohemia and Moravia look towards Vienna. In Slovakia the railways, with only one important exception, converge upon Budapest. The people appear to be alive to the necessity of remedying this state of affairs, and no fewer than fifteen new railways have been projected which, when completed, will unite Bohemia and Moravia more closely to one another and to Slovakia. Moreover, it is proposed to develop the waterways of the country by constructing a canal from the Danube at Pressburg to the Oder. If these improvements are carried out the position of CzechoSlovakia will, for an inland State, be remarkably strong. It will have through communication by 
water with the Black Sea, the North Sea, and the Baltic, and some of the most important land routes of the Continent already run through it. On the other hand, its access to the Adriatic is handicapped by the fact that in order to reach that sea its goods will have to pass through the territory of two, if not three, other States, and however well the doctrine of economic rights of way may sound in theory there are undoubted drawbacks to it in practice. It is probable, therefore, that the development of internal communications will in the end be to the advantage of the German ports, and more especially of Hamburg. But the other outlets of the State will certainly tend towards the preservation of its economic independence.

The exent to which Rumania has improved her position as a result of the war is for the present a matter of speculation. On one hand she has added greatly to the territory which she previously held, and superficially she has rendered it more compact; but on the other she has lost her unity of outlook, and strategically at least weakened her position by the abandonment of the Carpathians as her frontier. Again, whereas before the war she had a fairly homogencous population-probably from 90 to 95 per cent. of the $7,250,000$ people in the country being of Rumanian stock-she has, by the annexation of Transylvania, added an area of 22,000 square miles of territory, in which the Rumanians number less than one and a half millions out of a total of two and twothird millions. In that part of the Banat which she has obtained there is also a considerable alien element. It is in this combination of geographical division and ethnic intermixture that we may foresee a danger to Rumanian unity. The position in the Dobruja is also open to criticism. Geographically the region belongs to Bulgaria, and the Danube will always be regarded as their true frontier by the Bulgarian people. Ethnically its composition is very mixed, and, whatever it was originally, it certainly was not a Rumanian land. But after the Rumanians had rather unwillingly been compelled to accept it in exchange for Bessarabia, filched from them by the Russians, their numbers increased and their economic development of the region, and more especially of the port of Constanza, undoubtedly gave them some claims to the northern part of it. As so often happens, however, when a country receives part of a natural region beyond its former boundaries, Rumania is fertile in excuses for annexing more of the Dobruja. To the southern part, which she received after the Balkan wars, and in the possession of which she has been confirmed by the peace terms with Bulgaria, she has neither ethnically nor economically any manner of right. Her occupation of it will inevitably draw Rumania on to further intervention in Bulgarian affairs. The arrangements which have been made with regard to the Banat must be considered in relation to the Magyar position in the Hungarian plain. The eastern country of the Banat, Krasso-Szörény, has a population which is in the main Rumanian, and as it belongs to the Carpathian area it is rightly included with Transylvania in Rumanian territory. In the remainder of the Banat, including Arad, the Rumanians form less than one-third of the total population, which also comprises Magyars, Germans, and Serbs. But Rumania has been permitted to descend from the mountains and Jugo-Slavia to cross the great river which forms her natural boundary, and both have obtained a foothold on the plain, where it may be only too easv for them to seek occasion for further advances. For the extension of Jugo-Slavia beyond NO. 2655 , VOL. IO6] the Danube two pleas have been advanced, one ethnical and the other strategic. Neither is really valid. The Danube is certainly a better defensive frontier than the somewhat arbitrary line which the Supreme Council has drawn across the Hungarian plain.

In fact, it is in the treatment of the Hungarian plain that we feel most disposed to criticise the territorial settlements of the Peace Treaties. Geographical principles have been violated by the dismemberment of a region in which the Magyars were in a majority, and in which they were steadily improving their position. Ethnical principles have been violated, both in the north, where a distinctly Magyar region has been added to Slovakia, and in the south, where the western part of the Banat and Bačlka have been divided between the Rumanians and the Jugo-Slavs, who together form a minority of the total population. For the transfer of Arad to Rumania and of the Burgenland to Austria more is to be said, but the position as a whole is one of unstable equilibrium, and can only be maintained by support from without. In this part of Europe at least a League of Nations will not have to seek for its troubles.

When we turn to Austria we are confronted with the great tragedy in the reconstruction of Europe. Of that country it could once be said, "Bella gerant alii, tu felix Austria nube," but to-day, when dynastic bonds have been loosened, the constituent parts of the great but heterogeneous empire which she thus built up have each gone its own way. And for that result Austria herself is to blame. She failed to realise that an empire such as hers could only be permanently retained on a basis of common political and economic interest. Instead of adopting such a policy, however, she exploited rather than developed the subject nationalities, and to-day their economic, no less than their political, independence of her is vital to their existence. The entire political reorientation of Austria is necessary if she is to emerge successfully from her present trials, and such a reorientation must be brought about with due regard to geographical and ethnical conditions. The two courses which are open to her lead in opposite directions. On one hand she may become a member of a Danubian confederation, on the other she may throw in her lot with the German people. The first would really imply an attempt to restore the economic position which she held before the war, but it is questionable whether it is either possible or expedient for her to make such an attempt. A Danubian confederation will inevitably be of slow growth, as it is only under the pressure of economic necessity that it will be joined by the various nationalities of southeastern Europe. Moreover, Austria has in the past shown little capacity to understand the Slav peoples, and in any case her position in what would primarily be a Slav confederation would be an invidious one. For these reasons we turn to the suggestion that Austria should enter the German Empire, which, both on geographical and on ethnical grounds, would appear to be her proper place. Geographically she is German, because the bulk of the territory left to her belongs either to the Alpine range or to the Alpine foreland. Ethnically, of course, she is essentially German. Now, although my argument hitherto has rather endeavoured to show that the transfer of territory from one State to another on purely economic grounds is seldom to be justified, it is equally indefensible to argue that two States which are geographically and ethnically related are not to be allowed to unite their fortunes because it would be to their interest to do so. And that it would be to 
their interest there seems little doubt. Austria would still be able to derive some of her raw materials and foodstuffs from the Succession States, and she would have, in addition, a great German area in which she would find scope for her commercial and financial activities. Not only would Austria find a market for her industrial products in Germany, but she would also become the great trading centre between Germany and south-east Europe.

The absorption of Austria in Germany is opposed by France, mainly because she cannot conceive that her great secular struggle with the people on the other side of the Rhine will ever come to an end, and she fears the addition of 6,500,000 to the population of her ancient enemy. But quite apart from the fact that Germany and Austria cannot permanently be prevented from following a common destiny if they so desire, and apart from the fact that politically it is desirable they should do so with at least the tacit assent of the Allied Powers rather than in face of their avowed hostility, there are reasons for thinking that any danger to which France might be exposed by the additional man-power given to Germany would be more than compensated for by the altered political condition in Germany herself. Vienna would form an effective counterpoise to Berlin, and all the more so because she is a great geographical centre, while Berlin is more or less a political creation. The South German people have never loved the latter city, and to-day they love her less than ever. In Vienna they would find not only a kindred civilisation with which they would be in sympathy, but also a political leadership to which they would readily give heed. In such a Germany, divided in its allegiance between Berlin and Vienna, Prussian animosity to France would be more or less neutralised. Nor would Germany suffer disproportionately to her gain, since in the intermingling of northern efficiency with southern culture she would find a remedy for much of the present discontents. When the time comes, and Austria seeks to ally herself with her kin, we hope that no impassable obstacle will be placed in her way.

The long and as yet unsettled controversy on the limits of the Italian kingdom illustrates very well the difficulties which may arise when geographical and ethnical conditions are subordinated to considerations of military strategy, history, and sentiment in the determination of national boundaries. The annexation of the Alto Adige has been generally accepted as inevitable. It is true that the population is German, but here, as in Bohemia, geographical conditions appear to speak the final word. Strategically also the frontier is good, and will do much to allay Italian anxiety with regard to the future. Hence, although ethnical conditions are to some extent ignored, the settlement which has been made will probably be a lasting one.

On the east the natural frontier of Italy obviously runs across the uplands from some point near the eastern extremity of the Carnic Alps to the Adriatic. The pre-war frontier was unsatisfactory for one reason, because it assigned to Austria the essentially Italian region of the Lower Isonzo. But once the lowlands are left on the west, the uplands which border them on the east, whether Alpine or Karst, mark the natural limits of the Italian kingdom, and beyond a position on them for strategic reasons the Italians have no claims in this direction except what they can establish on ethnical grounds. In Carniola the Slovenes are in a large majority, and in Gorizia they also form the bulk of the population. On the other hand, in the town and district of Trieste the

NO. 2655 , VOL. IO6]
Italians predominate, and they also form a solid block on the west coast of Istria, though the rest of that country is peopled mainly by Slovenes. It seems to follow, therefore, that the plains of the Isonzo, the district of Trieste, and the west coast of Istria, with as much of the neighbouring upland as is necessary to secure their safety and communications, should be Italian, and that the remainder should pass to the Jugo-Slavs. The so-called Wilson line, which runs from the neighbourhood of Tarvis to the mouth of the Arsa, met these requirements fairly well, though it placed from 300,000 to 400,000 Jugo-Slavs under Italian rule to less than 50,000 Italians, half of whom are in Fiume itself, transferred to the Jugo-Slavs. Any additional territory must, by incorporating a larger alien element, be a source of weakness and not of strength to Italy. To Fiume the Italians have no claim beyond the fact that in the town itself they slightly outnumber the Croats, though in the double town of Fiume-Sushak there is a large Slav majority. Beyond the sentimental reasons which they urge in public, however, there is the economic argument, which, perhaps wisely, they keep in the background. So long as Trieste and Fiume belonged to the same empire the limits within which each operated were fairly well defined, but if Fiume becomes Jugo-Slav it will not only prove a serious rival to Trieste, but will prevent Italy from exercising absolute control over much of the trade of Central Europe. Its development is more fully assured as the one great port of JugoSlavia than under any other form of government. With regard to Italian claims in the Adriatic little need be said. To the Dalmatian coast Italy has no right either on geographical or on ethnical grounds, and the possession of Pola, Valona, and some of the islands gives her all the strategic advantages which she has reason to demand.

Of the prospects of Jugo-Slavia it is hard to speak with any feeling of certainty. With the exception of parts of Croatia-Slavonia and of southern Hungary, the country is from the physical point of view essentially Balkan, and diversity rather than unity is its most pronounced characteristic. Ethnic affinity forms the real basis of union, but whether that union implies unity is another matter. It is arguable that repulsion from the various peoples-Magyars, Turks, and Austrians-by whom they have been oppressed, rather than the attraction of kinship, is the force which has brought the Jugo-Slavs together. In any case, the obstacles in the way of the growth of a strong national feeling are many. Religious differences are not wanting, and cultural conditions show a wide range. To build up out of elements in many respects so diverse a common nationality without destroying what is best in each will be a long and laborious task. Economic conditions are not likely to be of much assistance. It is true that they are fairly uniform throughout Jugo-Slavia, and it is improbable that the economic interests of different regions will conflict to any great extent. On the other hand, since each region is more or less selfsupporting, they will naturally unite into an economic whole less easily than if there had been greater diversity. What the future holds for Jugo-Slavia it is as yet impossible to say; but the country is one of great potentialities, and a long period of political rest might render possible the development of an important State.

This brings me to my conclusion. I have endeavoured to consider the great changes which have been made in Europe, not in regard to the extent to which they do or do not comply with the canons of 
boundary-making-for, after all, there are no frontiers in Europe which can in these days of modern warfare be considered as providing a sure defencebut in regard rather to the stability of the States concerned. A great experiment has been made in the new settlement of Europe, and an experiment which contains at least the germs of success. But in many ways it falls far short of perfection, and even if it were perfect it could not be permanent. The methods which ought to be adopted to render it more equable and to adapt it to changing needs it is not for us to discuss here. But as geographers engaged in the study of the ever-changing relations of man to his environment we can play an important part in the formation of that enlightened public opinion upon which alone a society of nations can be established.

\section{Economics and Statistics at the British Association.}

THE meetings of Section F (Economics and Statistics) at the recent meeting of the British Association at Cardiff were characterised by the greater part taken in the programme by the younger students of economics, and the result augurs well for the future of the science. What some of the readers of papers may have lacked in experience and authority they gained in freshness of outlook, in readiness to face the new facts of the post-war situation, and in refusal to be bound by the views of the older generation. It would have been interesting had some of the older representatives of the science been present to see the clash of the old ideas and the new; in their absence some of the less orthodox views went almost unchallenged.

In the first meeting of the Section the application of the co-operative method to economic life was urged in two connections. Mr. L. Smith Gordon (arguing from his experience of Irish conditions, in which he has been associated with Sir Horace Plunkett) dwelt on the necessity of treating agriculture as an industry to be organised on a scientific basis if its psychological and economic demands were to be reconciled with modern conditions. Such a scientific basis could only be found in co-operation. In his view, the undoubted advantages of large-scale farming lay not in the actual work of production, but in the handling and sale of the goods produced; and this thesis he maintained in an examination of the economies open to agriculture. But such advantages do not necessitate the existence of large farmers; the same results can be obtained through the adoption by small men of the co-operative methods already applied in Denmark, Belgium, and Germany, and this has the further advantage of building up a numerous race of independent, prosperous small farmers.

Mr. J. Lassen, a Dane, with twenty years' experience of England, argued for the introduction into this country of the Danish system of credit corporations, and supported his case by a detailed examination of the Danish method. The unique point of the system is that, whereas most financing is usually carried out through corporations of lenders (banks, trust companies, etc.), the Danish system begins with a corporation of borrowers. The borrowers, mainly belonging to one locality, and being known to each other, give joint security for loans, and the general public are asked to lend on this first-class mortgage security. That the system has worked well in Denmark was obvious from its history, but the writer was unable entirely to satisfy the sceptics on two points : first, how, if the system were introduced here, the hard-headed Englishman could be induced to accept unlimited liability; and, secondly, how the public could be induced to subscribe to bonds which are liable to depreciation and do not yield an abnormally high rate of interest. There seemed to be some subtle difference in the psychology' of the Dane and the Englishman which remained unexplained.

From co-operation the Section passed to the conNo. 2655 , VOL. IO6] sideration of coal. Mr. J. O. Cheetham analysed the present coal situation with special reference to its effects on the shipping interests of Cardiff. His main subject was the falling output, an examination of its causes and results, and suggestions for increasing production. In I9I 3 the coal produced in the United Kingdom amounted to $287,000,000$ tons, in I9I9 to $229,000,000$ tons-a fall of $58,000,000$ tons. In the same period the numbers employed in the industry increased from $1,128,000$ by 63,000 to $1,191,000$; and the output per person employed in the industry fell from 262 tons to 193 tons per annum. Thus an increase of 6 per cent. in the numbers employed synchronised with a decrease of 20 per cent. in total output. The writer also estimated (though from an ex parte statement by employers) that labour costs had increased from 63 per cent. of selling price in I9I4 to 75 per cent. of selling price in Igrg. Thus the period of Government control of the coal industry was also the period of the decline in total production and in production per head, and c, increase in relative labour costs of production. The special causes to which the decline in output was attributed were the introduction of the seven-hours' day and the failure of transport to convey the coal from the pit-head owing to the lack of trucks. In addition, the employers accused the miners of restricted production, and the employees in turn accused the owners of a deliberate holding-up of the development of mines. Mr. Cheetham seemed to hold both charges well grounded, but to think that what was a sin against the community on the part of the miners was natural and justifiable on the part of the owners-a distinction in which it was difficult to follow him. The president of the Section, Dr. Clapham, directed attention to the necessity of discovering to what extent the decreased output was attributable to the employment of a large amount of labour, not in getting coal, but in improving the state of the mines which had been inevitably neglected during the war period.

Mr. R. F. Adgie, in a paper entitled "The Conduct of the Mining Industry," distinguished between the economic and the psychological aspects of the problem of nationalisation. His thesis was that while from the purely economic point of view the argument for nationalisation was inconclusive, from the psychological viewpoint the balance of evidence pointed to the necessity of social ownership and control. On the economic side he pointed out that there had been an undefined amount of waste connected with the conduct of the industry under private ownership in the past. There was a good deal in distribution, since coal sold at the pit-head for $23^{s}$. $5 \mathrm{~d}$. was sold to the London consumer at $44 \mathrm{~s}$., the distribution charges thus amounting to 47 per cent. This leakage, however, could be stopped by large-scale or unified distribution. In some other directions the economic defects of the industry in recent years (reduced output, inefficient working, etc.) were exigencies of the war period, and were rapidly disappearing; and in others uncoordinated effort and inadequate capital resources had 